University of Maryland Francis King Carey School of Law

DigitalCommons@UM Carey Law

$12-1-1992$

\title{
Myth and Reality: The Threat of Medical Malpractice Claims by Low Income Women
}

Karen $\mathrm{H}$. Rothenberg

University of Maryland School of Law, krothenberg@law.umaryland.edu

Follow this and additional works at: https://digitalcommons.law.umaryland.edu/fac_pubs

Part of the Health Law and Policy Commons

\section{Digital Commons Citation}

Rothenberg, Karen H., "Myth and Reality: The Threat of Medical Malpractice Claims by Low Income Women" (1992). Faculty Scholarship. 161.

https://digitalcommons.law.umaryland.edu/fac_pubs/161

This Article is brought to you for free and open access by the Francis King Carey School of Law Faculty at DigitalCommons@UM Carey Law. It has been accepted for inclusion in Faculty Scholarship by an authorized administrator of DigitalCommons@UM Carey Law. For more information, please contact smccarty@law.umaryland.edu. 


\title{
Myth and Reality:
}

\section{The Threat of Medical Malpractice Claims}

\author{
by Low Income Women
}

\author{
Karen H. Rothenberg
}

Physician reluctance to treat poor and minority women is often attributed to three factors-rate of reimbursement, health status of the patient and perception of increased malpractice liability ${ }^{3}$ - which intertwine in a vicious cycle that contributes to the exclusion of low income and minority women from health care. The prospect and reality of insufficient or non-existent reimbursement for provider services produces an unwillingness to accept poor or poorly insured patients. This reluctance is reinforced by rising medical malpractice premiums ${ }^{2}$ and the perception that the reduced rate of reimbursement received for low income patients does not justify the increased risk of malpractice liability. ${ }^{3}$

The belief that the poor are more likely to sue is a misperception that urgently needs to be corrected. Many physicians view low income patients as "more litigious" 4 than middle claşs or wealthy patients, despite mounting evidence to the contrary. In fact, over the last few years providers have successfully argued before state legislatures that they should be immunized from liability for damages for injury or death resulting from negligence when the services were provided "without the expectation or receipt of compensation." Such legislation is framed as "good samaritan" laws to encourage the provision of services to the poor and uninsured without threat of suit. ${ }^{7}$

Low income women may, in fact, be more likely to suffer adverse outcomes." Although the relationship between minority status and adverse outcomes has not been adequately investigated, " statistically higher adverse outcones for the poor may be attributable to lack of access to the system, especially for primary and prenatal care, or discriminatory and inadequate care once in the system. ${ }^{\circ}$ The predicament of pregnant drug addicted women is a case in point. Currently, many HIV-positive women are injection drug users or the partners of injection drug users. ${ }^{\text {II }}$ Viewed as non-compliant ${ }^{12}$ and obstetrically risky patients, ${ }^{13}$ drug addicted women have little chance of enlisting professional help to get clean during their pregnancy because the overwhelming majority of drug treatment programs refuse to accept pregnant women due to fear of incurring "pregnancy-related legal liability." ${ }_{14}$ This almost blanket exclusion from drug treatment programs continues despite new studies which indicate that intensive prenatal care for pregnant drug addicts results in substantially improved obstetrical outcomes. ${ }^{15}$ Based on misfounded perceptions of potential liability, the exclusion of drug addicted women overwhelmingly impacts on poor and minority women and the children they bear.

In fact, such fear of tort liability has taken on mythic qualities: yet the fear is far out of proportion to the reality' ${ }^{16}$ and is one factor which erodes access to both primary and reproductive related health care for poor and minority women. Litigation infrequently compensates patients injured by medical negligence and rarely identifies, and holds providers accountable for, substandard care." " 7 A recent malpractice study ${ }^{18}$ conducted in New York State correlated malpractice claims to actual adverse events caused by negligence by matching malpractice claims to inpatient medical records. The study estimated that New York's statewide ratio of actually occurring adverse events caused by negligence to malpractice claims filed was 7.6 to $\mathrm{r}^{19}$ 
When translated into percentages, this relative frequency means that "the fraction of medical negligence which leads to claims is probably under 2 percent." ${ }^{20}$ The adverse events caused by negligence were highest among the poor and minority patients. ${ }^{21}$

The structure of the tort system itself may effectively minimize provider liability. In fact, when a typical tort suit is dissected into its component parts, the reasons why liability is underrepresented become apparent. The beginnings of any tort suit necessarily lie in the recognition that some injury or harm, which should not have occurred, did occur. But, how often can lay people recognize negligence in an area as complex as medicine? The ability to recognize the occurrence of a negligent medical injury may be contingent upon socioeconomic factors such as educational level and past familiarity with the health care system as well as access to further care, which may identify the occurrence of an injury. ${ }^{22}$ As studies of actual malpractice claims filed document, ethnic minorities and the poor are no more likely to sue $^{23}$ and are statistically less likely to sue $^{24}$ than other socioeconomic groups although they may experience statistically higher occurrences of adverse events. ${ }^{25}$ In addition to the lack of education and lack of access to care as factors which contribute to the inability to perceive that a medical injury has occurred, minorities and the poor, who are already disenfranchised from the health and justice systems, may be disinclined to work within the system to assert claims to address wrongful injuries. Disenfranchisement may also lead to different expectations as to quality of care and redressability of wrongs. Medical injury may be just one more problem in a life characterized by unrelenting adversity and social and economic impoverishment.

If a negligently induced injury is recognized, legal representation must be obtained in order to sue. Unlike some legal disputes (e.g. small claims), the complexity of most medical negli- gence cases necessitates legal representation. However, the tort system functions as a barrier preventing many poor people from obtaining legal counsel for medical malpractice actions. ${ }^{26}$ Plaintiff's attorneys accept tort cases on a contingency basis, with the attorney receiving a percentage amount recovered for the client plus the costs of litigating the claim, which may be substantial depending on the complexities of the cases. Contingency fees are inherently financially risky: losing the suit means no compensation for the attorney, as well as the clicnt, even though the attorncy expended considerable time and money pursuing the claim. ${ }^{27}$

Since recovery in tort is based on compensatory damages, which are measured at least in part by the economic impact of the injury, (e.g. lost income and impaired earning ability), undereducated, unskilled, unemployed and underemployed people will be awarded substantially less in compensatory damages than well educated, higher earning people for the same injury.

Even if legal representation is obtained, the plaintiff must be prepared to wait a substantial period of time for settlement or litigation: lawsuits can take years to wind through the courts. Consider, for example, the HIV-positive woman, who may be too sick to cope with, or survive, a lengthy law suit through its trial and appellate phases. If the woman becomes too ill or dies, will her familiy be able to continue the suit? Since AIDS is a disease which devastates entire families, often claiming the woman last, no family may be left living, or left living in sufficiently good health, to carry the suit forward. Or, the family, in its struggle to care for those the woman left behind, such as her children, who may also be infected and ill, may not be able to cope with protracted litigation. Even in those relatively few jurisdictions, which funnel cases through alternative dispute resolution mechanisms for more rapid resolution, de- fense counsel can often circumvent final settlement for years.

Assuming the woman and her family are committed to spending years litigating the suit, who will provide financial support during those year's? If damages are ultimately recovered, the resultant boost in income may remove the woman and her children from eligibility for governmental benefits, especially health care benefits. ${ }^{28}$ On balance, loss of governmental assistance may not be worth the cost of settling or winning the suit. ${ }^{29}$

We can no longer perpetuate the myth of medical malpractice suits by the poor to further erode access to medical care. Rather, we must educate providers, consumers, and policy makers to provide better health care for all, regardless of economic status. Hiding behind the threat of a professional liability suit just won't do it.

\section{References}

I. Mary G. : Mussman, Lu Zawistowich, Carol S. Weisman, Faye E. Malitz and Laura Morelock, "Medical Malpractice Claims Filed by Medicaid and Non-Medicaid Recipients in Maryland," 265 JAMA 2992 (June I2, I99I).

2. Jan Perkins and Kathleen Stoll, "Medical Malpractice: A Crisis for Poor Woman," Clearinghouse Review 1277 (Feb. 1987).

3. Supra note I at 2992. ("The cost of inalpractice insurance is thought to deter physicians from participating because Medicaid payment is insufficient to compensate for rising premiums...").

4. $I d$.

5. David Hilfiker, "Are Poor Patients More Likely to Sue for Malpractice?" 262 JAMA I39 I-I 392 (September $8,1989)$ and Perkins supra note 2 at $1278-79$.

6. Emphasis added. $\$ 5 \mathrm{I}-\mathrm{I}-29.1$ of Georgia Code provides:

(a) ...unless it is established that injuries or death were caused by gross negligence or willful or wanton misconduct:

(I) No health care provider ... who voluntarily and without the expectation or receipt of compensation provides professional services, within the scope of such health care provider's licensure, for and at the request of a hospital, public school, nonprofit organization, or an agency of the state or one of its political subdivi- 
sions or provides such professional services to a person at the request of such organization, which organization does not expect or receive compensation with respect to such services from the recipient of such services; or

(2) No licensed hospital, public school, or nonprofit organization, which requests, sponsors, or participates in the providing of the services under the circumstances provided in paragraph (I) of this subsection shall be liable for damages or injuries alleged to have been sustained by the person nor for damages for the injury or death of the person when the injuries or death are alleged to have occurred by reason of an act or omission in the rendering of such services.

See also $\$ 8.01-225$ of the Code of Virginia which provides in part:

Any person who, in the absence of gross negligence, renders emergency obstetrical care or assistance to a female in active labor who has not previously been cared for in connection with the pregnancy by such person or by another professionally associated with such person and whose medical records are not reasonably available to such person shall not be liable for any civil damages for acts or omissions resulting from the rendering of such emergency care or assistance. The immunity herein granted shall apply only to the emergency medical care provided.

A number of more general immunity statutes have passed nationwide to immunize "volunteers" who provide medical services, regardless of the setting.

7. See Karen H. Rothenberg, "Who Cares? The Evolution of the Legal Duty to Provide Emergency Care," 26 Houston L. Rev. 2 I (1989).

8. Supra note 2 at 1278 . ("Pregnant women on Medicaid or with no insurance are included in most practitioners' definitions of "high risk," because these women more often receive no prenatal care and exhibit other indications of pregnancy complications such as inadequate diet and high stress.") and Supra note I at 2992.

9. Troyen Brennan, Liesi E. Hebert, Nan M. Laird, Ann Lawthers, Kenneth E. Thorpe, Lucian L. Leape, A. Russell Localio, Stuart R. Lipsitz, Joseph P'. Newhouse, Paul C. Weiler, and Howard H. Hiatt, "Hospital Characteristics Associated with Adverse Events and Substandard Care," 265 JAMA 3265 (June 26, 1991). Io. Id.

I I. CDC, "Update: Acquired Immunodeficiency Syndrome-United States, I98I-1990," 4O(2) MMWR 358 (June 7, I99I). ("A history of IV-drug abuse was reported by $2329(47.6 \%)$ women with AIDS. Heterosexual contact with a man infected with HIV or at high risk for HIV infection accounted for $1657(33.9 \%)$ cases among women; $64.1 \%$ of these male sexual partners were IV-drug users.")

I 2. Carole Levine, "Women and HIV/ AIDS Research: The Barriers to Equity," I 4 Evaluation Review 447,449 (1990).

13. Molly McNulty, "Combating Pregnancy Discrimination in Access to Substance Abuse Treatment for Low-Income Women," Clearinghouse Review $2 \mathrm{I}$, 22 (May I 989). ("Most drug treatment programs categorically do not admit pregnant addicts, because clinics lack obstetrical expertise, because a pregnant addict is considered "high-risk" and drains away a disproportionate share of treatment resources, or because they fear obstetrical malpractice suits. likewise, prenatal care centers often turn away pregnant women who are addicts, because they lack drug treatment capacity, or because they wish to avoid treating high-risk patients.")

14. See e.g., Teri Randall, "Intensive Prenatal Care May Deliver Healthy Babies to Pregnant Drug Abusers," 265 JAMA 2773-2774 (June 5, r99 I).

I5. Id.

I6. A survey of New York physicians in 1989 found that "on average, physicians estimate that 19.5 out of one hundred of their colleagues will be sued in a given year, approximately three times the actual rate, with significant differences by specialty, location, and suit history .... High risk specialties (obstetrics, orthopedics, and neurosurgery) had a perceived risk of being sued that was almost three times that of low-risk specialties (internal medicine and associated subspecialties) and 76 percent higher than the overall average perceived risk of 19.5 suits per one hundred physicians." "Pliysicians" Perceptions of the Risk of Being Sued," A.G. Lawthers, A.R. Localio, N.M. Laird, et al., Journal of Health Politics, Policy and Law 17:3, 1992.

17. A.R. Localio, A.G. Lawthers, T.A. Brennan, N.M. Laird, L.E. Herbert, L.M. Peterson, J.P. Newhouse, P.C. Weiler, H.H. Hiatt, "Relation Between Malpractice Claims and Adverse Events Due to Negligence: Results of the Harvard Medical Practice Study III," 325(4) N. Engl. J. Med. 245-5 I, 250 (July 25, I 99 I).

This result corroborates earlier studies and reports, such as one study conducted in California which concluded that "for each medical malpractice claim, ro injuries were caused by negligent care," (Id. at 245 ) and a report which found that "[n]inety percent of the potentially successful causes of action due to medical negligence never result in lawsuits." Supra note 2 , at 1280 .

I $8 . I d$.

20. Id. at 249 .

21. Empirical evidence suggests providers can reduce actual malpractice claims by all socioeconomic groups by improving communications with patients. Gerald Hickson, Ellen Wright Clayton, Penney Githens, and Frank Sloan, "Factors that Prompted Families to File Medical Malpractice Claims Following Perinatal Injuries," 267 JAMA I 359-I 363 (March I I, 1992). A recent study, which surveyed I 27 Floridian families who had filed claims for birth-related injuries, examined the reasons why families filed lawsuits. The reasons cited are illuminating: while $24 \%$ filed to obtain funds for longIcrin care, $20 \%$ filed when they realized the child had "no future"; $19 \%$ wanted to deter future incidents of malpractice or obtain revenge on the physician; $33 \%$ filed because someone, often another doctor, advised them to file, (or alternatively, the families interpreted subsequent treating physician comments as recognition of an injury or advice to sue); $24 \%$ filed because their physician was not honest about the circumstances of the injury; and $20 \%$ filed because it was the only way the families could determine what caused the injury. Families believed physicians failed to recognize fetal distress ( $53 \%$ of sample), manage fetal distress properly $(57 \%)$, or perform a caesarean section (33\%) or that physicians were unavailable when needed $(29 \%)$.

22. Supra note 2, at I 280.

23. Supra note 5 at I391-1392. ("The perception that poor patients sue more for medical malpractice is a damaging nyth.")

24. Id; See also supra note 2 , at 1280.

25. Supra note 9.

26. $1 d$.

27. In contrast, medical malpractice defense work is generally conducted on a hourly charge basis, with the attorney recovering regardless of the outcome.

28. Id.

29. Of course, this conclusion may change in the context, for example, of women and the AIDS epidemic. When HIV begins to affect increasing numbers of white, middle class women, the risk calculus may be altered. This group of women may be more likely to recognize the occurrence of an injury, better able to afford to sue, more likely to have family members able to press the suit, and more likely to recover a larger judgment. 